\title{
Gênero e subjetividade em O Dominó Preto e Diário, de Florbela Espanca
}

\author{
Bárbara Patoléa Monteiro Correio ${ }^{\mathrm{i}}$
}

\section{RESENHA}

ESPANCA, Florbela. Diário; O Dominó Preto. Organização, fixação crítica dos textos e notas de Fabio Mario da Silva. Estudos introdutórios de Fabio Mario da Silva e Isa Severino. Lisboa: Edições Esgotadas, 2019.

Florbela Espanca fez parte de uma geração de mulheres em Portugal que se beneficiaram de uma gradual transformação social que possibilitou a entrada de meninas nos liceus. A intrepidez já manifestada no fato de ter sido uma das poucas a frequentar um colégio de presença convencionalmente masculina foi perceptível em outros eventos ao longo da sua vida, uma vez que, mais tarde, Florbela viria a se inserir em um cenário literário de tradição masculina, assim como também faria questionamentos acerca das condições impostas às mulheres. Apesar de ter alcançado seu devido reconhecimento somente depois da morte, Florbela foi, e ainda é, figura central de estudo de importantes pesquisadores.

Dentre as iniciativas recentes de publicação da obra florbeliana, merece destaque a empreendida pela editora Edições Esgotadas, que assumiu o desafio de continuar a reedição das obras completas de Florbela Espanca, projeto este que antes teve o apoio da extinta Editorial Estampa, responsável por trazer a lume os quatro primeiros volumes: Livro de Mágoas (2012), Livro de Soror Saudade (2012), Charneca em Flor (2013) e As Máscaras do Destino (2015). Cláudia Pazos Alonso e Fabio Mario da Silva foram os encarregados da organização, notas e fixação crítica dos textos, no qual podemos ver um trabalho minucioso e de alta qualidade.

Para cada volume das obras completas de Florbela Espanca, foram convidados vários especialistas para compartilharem suas perspectivas e fornecerem uma

\footnotetext{
${ }^{\text {i }}$ Mestranda em Literatura Portuguesa pela Universidade do Estado do Rio de Janeiro (UERJ), sob orientação do Prof. Doutor Henrique Marques Samyn.

ORCID: https://orcid.org/0000-0003-4708-5761 | barbarapatolea@gmail.com
} 
informação crítica mais abalizada, oferecendo ao leitor diferentes abordagens a respeito das obras da autora. Neste mais novo volume, produzido entre 2016 e 2018, além de encontrarmos um estudo introdutório do organizador Fabio Mario da Silva acerca dos papéis de gênero no livro de contos $O$ Dominó Preto, nos deparamos com uma análise da Professora Doutora Isa Margarida Vitória Severino, que se dedica ao estudo do Diário florbeliano.

Elaborado entre 11 de janeiro e 2 de dezembro de 1930, findando dias antes da sua morte, o Diário de Florbela Espanca foi publicado pela primeira vez em 1981, pela Editora Bertrand. Segundo relata Isa Severino, apesar do Diário do Último Ano se apresentar de uma forma curta em relação à obra poética da autora, este documento, publicado postumamente, aparenta "manter uma linha de continuidade e de diálogo com a sua poesia" (2019, p. 37), em que podemos perceber não só a semelhança de temas como, também, a constante presença de um conflito do "eu" consigo mesmo. Além disso, tudo indica que Florbela escreve o Diário com a esperança de ser lida por alguém, de maneira que a leitura feita por esse "outro" possa levar a um desvelamento de si mesma. Seja por meio da sua poesia ou diário, Florbela Espanca está sempre em busca por caminhos para externar seus sentimentos e à procura de respostas a respeito dos questionamentos mais profundos de sua mente:

\footnotetext{
À semelhança do que sucede na sua poesia, também o Diário evidencia uma tentativa de construção identitária. O primeiro fragmento, datado de 11 de janeiro de 1930, inicia com uma sucessão de perguntas retóricas, revelando um «eu» em constante deambulação entre si e o «outro», um possível leitor/a que contribua para o seu autoconhecimento. (SEVERINO, 2019, p. 37)
}

Como critérios de fixação do texto, do mesmo modo como nos volumes precedentes das obras completas, a grafia e acentuação desta nova edição foram alteradas conforme as regras em vigência; mas, com o intuito de preservar o estilo da autora, a pontuação foi mantida de acordo com a edição impressa de 1931.

Nos últimos anos de sua vida, ao longo dos quais Florbela preparou Charneca em Flor - seu último livro de poesia, que seria publicado postumamente -, a autora também se dedicou a uma produção em prosa que pretendia publicar em outubro de 1927: O Dominó Preto. Por conta de um trágico acidente envolvendo seu irmão mais novo, Apeles Espanca, o projeto ficou interrompido até muitos anos depois. O que se sabe é que alguns contos deste livro já teriam sido publicados em jornais quando 
Florbela ainda estava viva (sendo desconhecidas versões publicadas em periódicos ou cópias manuscritas dos contos "Amor de Outrora" e "O crime do Pinhal do cego").

Embora surjam questionamentos a respeito dos títulos como os conhecemos hoje em dia, tudo indica que a ordem em que os contos aparecem tenha sido realmente escolhida por Florbela. Para preparar essa edição, Fabio Mario da Silva utilizou os manuscritos disponíveis, comparando-os com as versões da Editora Bertrand e dos periódicos já divulgados anteriormente. Para os contos em que o original não é conhecido, foi utilizada a versão do ano de 1982, mas sempre levando em consideração as particularidades da escrita da autora.

Em seu estudo introdutório presente neste volume das obras completas de Florbela Espanca, Fabio Mario da Silva nos conta como a autora percebe, tanto no seu livro de contos $O$ Dominó Preto como no Diário, a urgência de dar protagonismo às mulheres, com a finalidade de "esboçar diferentes imagens femininas" (SILVA, 2019, p. 71). Essas duas produções evidenciam de forma mais clara o que Florbela já tinha planejado em As Máscaras do Destino e nas suas poesias. Através de suas obras, a poetisa tencionava nos levar a compreender as novas concepções que começavam a manifestar-se no cenário português contemporâneo, de modo que houvesse uma abertura maior acerca dos papéis de gênero.

\section{Referências}

SEVERINO, Isa Margarida Vitória. "A Construção da Persona no Diário de Florbela". In: ESPANCA, Florbela. Diário; O Dominó Preto. Organização, fixação crítica dos textos e notas de Fabio Mario da Silva. Lisboa: Edições Esgotadas, 2019.

SILVA, Fabio Mario da. "Algumas facetas femininas. Uma leitura dos contos de $O$ Dominó Preto, de Florbela Espanca.” In: ESPANCA, Florbela. Diário; O Dominó Preto. Organização, fixação crítica dos textos e notas de Fabio Mario da Silva. Lisboa: Edições Esgotadas, 2019. 